Check for updates

Cite this: RSC Adv., 2017, 7, 40067

\title{
Synthesis and evaluation of the antitumor activity of highly functionalised pyridin-2-ones and pyrimidin-4-ones $\dagger$
}

\author{
Xuan-Xuan Du, \$ Rong Huang, \$ Chang-Long Yang, Jun Lin (D)* \\ and Sheng-Jiao Yan (iD *
}

The methods for the synthesis of two novel types of compounds, including pyridin-2-ones 3 and pyrimidin4 -ones 4 were developed. Pyridin-2-ones 3 were synthesised via the regioselective reaction of $N, N^{\prime}$ disubstituted 1,1-ene diamines $1 \mathrm{a}-1 \mathrm{w}$ with mercaptals $2 \mathrm{a}-2 \mathrm{c}$ in acetonitrile promoted by $\mathrm{Cs}_{2} \mathrm{CO}_{3}$ under refluxing conditions. Fortunately, pyrimidin-4-ones 4 were obtained when the $N$-monosubstituted 1,1ene diamines $1 x-1 b^{\prime}$, used as substrate, by accident, reacted with mercaptals 2 under similar conditions. As a result, two kinds of novel heterocycles were synthesised by this protocol. The reactions have some advantages, such as excellent yield, inexpensive raw materials and convenient final treatment. The antitumor bioactivity screening showed that certain compounds had potent antitumor activity. Especially, compounds $3 r$, which showed the most potent activity with $\mathrm{IC}_{50}$ values lower than $12.3 \mu \mathrm{mol} \mathrm{L} \mathrm{L}^{-1}$ against four human tumor cell lines, making it more active than cisplatin (DDP). In addition, a preliminary assessment of the structure-selectivity relationship of the compounds was also performed.

Received 9th June 2017

Accepted 9th August 2017

DOI: $10.1039 / \mathrm{c} 7 \mathrm{ra06466g}$

rsc.li/rsc-advances discovery and screening, a concise and efficient one-pot parallel synthesis is very desirable.

The pyrimidin-4-one also has various biological activities and is widely used as an inhibitor of the enzyme reverse transcriptase to develop anti-HIV drugs, such as MK0518 and dihydro-alkylthio-benzyl-oxopyrimidines (S-DABOs) (Fig. 1), ${ }^{20,21}$ tenofovir, dapivirine, MIV150, UC781, UAMC01398, and DABO. ${ }^{22-26}$ In addition, it is also used in the development of various other drugs, including anti-schizophrenia, ${ }^{27}$ and endothelial cell dysfunction inhibitors, ${ }^{28}$ phosphoinositide 3-kinase inhibitors, ${ }^{29}$ CXCR3 antagonists, ${ }^{30}$ etc. ${ }^{31-33}$ Accordingly, various pyrimidin-4-ones have been obtained by many groups. ${ }^{34}$ and chemical scientists. Various methods for the synthesis of this compound have been reported, ${ }^{17-19}$ including $[1+2+3]$ cyclization, $[3+3]$ cyclization, rearrangement process, etc. The synthesis of pyridin-2-ones have made important contributions to the development of pyridin-2-ones compounds and their application. However, some of the existing synthesis methods have certain limitations, such as the use of high temperature, strong acid, metal catalyst or multiple steps. To meet the demands of drug

Key Laboratory of Medicinal Chemistry for Natural Resource (Yunnan University), Ministry of Education, School of Chemical Science and Technology, Yunnan University, Kunming, 650091, P. R. China.E-mail: linjun@ynu.edu.cn; yansj@ynu. edu.cn; Fax: +86871 65031633; Tel: +8687165031633

$\dagger$ Electronic supplementary information (ESI) available: CCDC 1549520 (3f), 1553238 (4f). For ESI and crystallographic data in CIF or other electronic format see DOI: $10.1039 / \mathrm{c} 7 \mathrm{ra06466g}$

$\ddagger$ The two authors contributed equally to this paper.

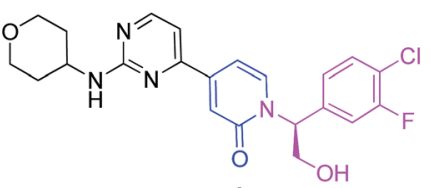

A

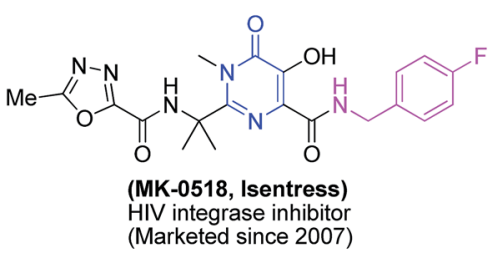

(Marketed since 2007)

Fig. 1 Biological activity pyridin-2-ones \& pyrimidin-4-ones.

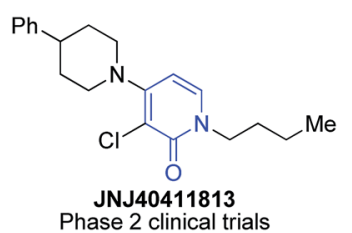

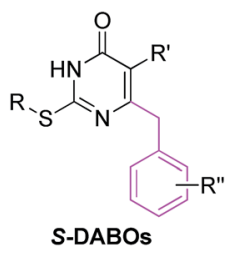


Our group has been applying the one-step strategy to construct drug-like $N$-containing heterocycles for many years. ${ }^{35-37}$ One-step strategies usually have some advantages over other methods, such as excellent yield, inexpensive raw materials and convenient final treatment, which reduce the production cost and avoid or reduce the environmental pollution.

1,1-Ene Diamines (EDAMs) serve as important and useful building blocks to construct various fused heterocyclic compounds including pyridines, ${ }^{38}$ 1,4-dihydropyridine, ${ }^{39}$ pyridin-2-ones, ${ }^{40}$ indoles, isoquinolinone, etc. ${ }^{41,42}$ have a broad range of biological activities. ${ }^{43}$ The novel properties of the chemical reaction of EDAMs, which serve as diversity building blocks, need to be explored in order to further widely use these blocks for the synthesis of heterocycles with potential biological activity to meet the demands of high activity screen.

In this paper, pyridin-2-ones 3 are synthesised by a one-step cascade reaction of $N, N^{\prime}$-disubstituted 1,1-ene diamine (DEDAM) 1 with 2, which was promoted by $\mathrm{Cs}_{2} \mathrm{CO}_{3}$. Pyrimidin4-ones 4 are also prepared based on the cascade reaction of the $N$-monosubstituted 1,1-ene diamine (MEDAM) 1 with 2 under similar conditions. As a result, the target compounds 3-4 are obtained with medium to good yields (83-98\%). The reaction has good substrate adaptability (aromatic ring, aromatic heterocyclic, alkyl), and the target product has the characteristics of molecular diversity $(\mathrm{R}=\mathrm{Ar}, \mathrm{Alk})$.

\section{Results and discussion}

First, $N, N^{\prime}$-disubstituted 1,1-ene diamine (DEDAM) 1a is used as substrate and is reacted with ethyl 2-cyano-3,3-bis(methylthio)-

Table 1 Optimism conditions for synthesis of pyridin-2-one $3 a^{a}$

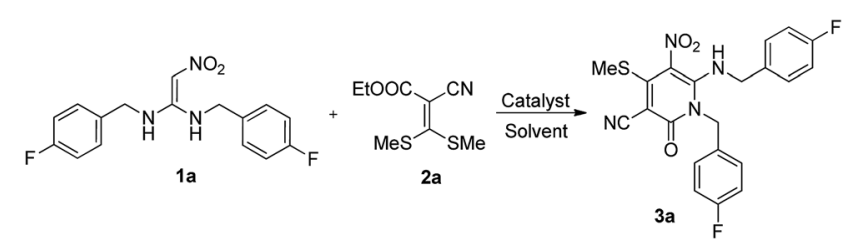

\begin{tabular}{llllll}
\hline Entry & Solvent & Base & $t\left[{ }^{\circ} \mathrm{C}\right]$ & Time $[\mathrm{h}]$ & Yield $^{b}[\%]$ \\
\hline 1 & 1,4-Dioxane & - & Reflux & 8 & 10 \\
2 & EtOH & - & Reflux & 8 & N.R. \\
3 & THF & - & Reflux & 8 & N.R. \\
4 & DMF & - & Reflux & 8 & 15 \\
5 & $\mathrm{CH}_{3} \mathrm{CN}$ & - & Reflux & 8 & 40 \\
6 & $\mathrm{CH}_{3} \mathrm{CN}$ & $\mathrm{Et}_{3} \mathrm{~N}$ & Reflux & 8 & 65 \\
7 & $\mathrm{CH}_{3} \mathrm{CN}$ & $\mathrm{K}_{2} \mathrm{CO}_{3}$ & Reflux & 8 & 75 \\
8 & $\mathrm{CH}_{3} \mathrm{CN}$ & $\mathrm{Cs}_{2} \mathrm{CO}_{3}$ & Reflux & $\mathbf{8}$ & $\mathbf{8 9}$ \\
9 & $\mathrm{CH}_{3} \mathrm{CN}$ & $t-\mathrm{BuOK}$ & Reflux & 8 & 70 \\
10 & $\mathrm{CH}_{3} \mathrm{CN}$ & $\mathrm{Cs}_{2} \mathrm{CO}_{3}$ & Reflux & 4 & 68 \\
11 & $\mathrm{CH}_{3} \mathrm{CN}$ & $\mathrm{Cs}_{2} \mathrm{CO}_{3}$ & Reflux & 12 & 87
\end{tabular}

${ }^{a}$ Reagents and conditions: $N, N^{\prime}$-disubstituted 1,1-ene diamine (DEDAM) 1a $(1.0 \mathrm{mmol})$, mercaptal $2 \mathrm{a}(1.0 \mathrm{mmol})$, base $(2.0 \mathrm{mmol})$ and solvent $(15.0 \mathrm{~mL}) .{ }^{b}$ Isolated yield based on 1a. N.R. $=$ no reaction. acrylate 2a in 1,4-dioxane at reflux for 8 hours and we obtained the target compound 3a with very low yield (10\%). Then, different solvents including 1,4-dioxane, ethanol, tetrahydrofuran (THF), $N, N$-dimethylformamide (DMF) and acetonitrile are assessed at reflux (Table 1, entries 1-5). The results showed that the best solvent is acetonitrile and we obtained the target compound 3a with $40 \%$ yield. Based on the optimal solvent, we further evaluated the alkali, such as $\mathrm{Et}_{3} \mathrm{~N}, \mathrm{~K}_{2} \mathrm{CO}_{3}, \mathrm{Cs}_{2} \mathrm{CO}_{3}$, KOBu- $t$ (Table 1, entries 6-9). The results demonstrated that $\mathrm{Cs}_{2} \mathrm{CO}_{3}$ can promote the reaction and largely increase the yield and we ultimately obtained the product with a good yield (89\%). Finally, the reaction times were tested (Table 1, entries $8 v$ s. 10-11). The results revealed that the optimal reaction time is about 8 hours. Accordingly, we conclude that the optimal conditions are acetonitrile as solvent and $\mathrm{Cs}_{2} \mathrm{CO}_{3}$ as a base at reflux of 8 hours.

To expand the scope and application of this protocol, DEDAMs $(n=1,2,3,4)$ bearing different aromatic groups, including $p-\mathrm{CF}_{3} \mathrm{C}_{6} \mathrm{H}_{4}, p-\mathrm{FC}_{6} \mathrm{H}_{4}, p-\mathrm{ClC}_{6} \mathrm{H}_{4}, \mathrm{C}_{6} \mathrm{H}_{5}, p-\mathrm{MeC}_{6} \mathrm{H}_{4}$, $p-\mathrm{MeOC}_{6} \mathrm{H}_{4}, \quad m-\mathrm{CF}_{3} \mathrm{C}_{6} \mathrm{H}_{4}, \quad o-\mathrm{FC}_{6} \mathrm{H}_{4}, \quad m-\mathrm{FC}_{6} \mathrm{H}_{4}, \quad m-\mathrm{ClC}_{6} \mathrm{H}_{4}$,

Table 2 Preparation of pyridin-2-ones $3 a-3 y^{a}$

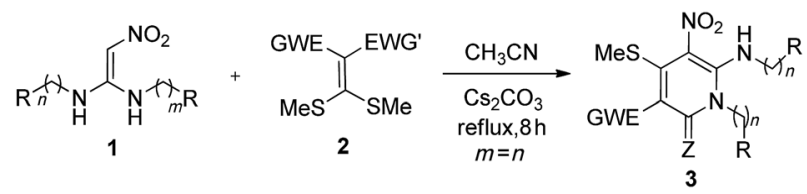

\begin{tabular}{|c|c|c|c|c|c|c|c|}
\hline Entry & $1 / \mathrm{R}$ & EWG & $\mathrm{EWG}^{\prime}$ & $n$ & $\mathrm{Z}$ & Pr & Yield $^{b}[\%]$ \\
\hline 1 & $1 \mathrm{a} / p-\mathrm{CF}_{3} \mathrm{C}_{6} \mathrm{H}_{4}$ & $\mathrm{CN}$ & COOEt & 1 & $\mathrm{O}$ & $3 \mathbf{a}$ & 92 \\
\hline 2 & $\mathbf{1 b} / p-\mathrm{FC}_{6} \mathrm{H}_{4}$ & $\mathrm{CN}$ & COOEt & 1 & $\mathrm{O}$ & $3 \mathbf{b}$ & 89 \\
\hline 3 & $1 \mathrm{c} / p-\mathrm{ClC}_{6} \mathrm{H}_{4}$ & $\mathrm{CN}$ & COOEt & 1 & $\mathrm{O}$ & $3 c$ & 87 \\
\hline 4 & $\mathbf{1 d} / \mathrm{C}_{6} \mathrm{H}_{5}$ & $\mathrm{CN}$ & COOEt & 1 & $\mathrm{O}$ & $3 d$ & 92 \\
\hline 5 & 1e/ $/ p-\mathrm{MeC}_{6} \mathrm{H}_{4}$ & $\mathrm{CN}$ & COOEt & 1 & $\mathrm{O}$ & $3 e$ & 85 \\
\hline 6 & 1f $/ p-\mathrm{MeOC}_{6} \mathrm{H}_{4}$ & $\mathrm{CN}$ & COOEt & 1 & $\mathrm{O}$ & $3 f$ & 84 \\
\hline 7 & $1 \mathrm{~g} / 3,4-\mathrm{F}_{2} \mathrm{C}_{6} \mathrm{H}_{3}$ & $\mathrm{CN}$ & COOEt & 1 & $\mathrm{O}$ & $3 g$ & 94 \\
\hline 8 & $\mathbf{1 h} / 2,4-\mathrm{F}_{2} \mathrm{C}_{6} \mathrm{H}_{3}$ & $\mathrm{CN}$ & COOEt & 1 & $\mathrm{O}$ & $3 \mathbf{h}$ & 96 \\
\hline 9 & $1 \mathrm{i} / 2,4-\mathrm{Cl}_{2} \mathrm{C}_{6} \mathrm{H}_{3}$ & $\mathrm{CN}$ & COOEt & 1 & $\mathrm{O}$ & $3 \mathbf{i}$ & 90 \\
\hline 10 & $\mathbf{1 d} / \mathrm{C}_{6} \mathrm{H}_{5}$ & $\mathrm{CN}$ & $\mathrm{CN}$ & 1 & $\mathrm{NH}$ & $3 \mathbf{j}$ & 83 \\
\hline 11 & $\mathbf{1} \mathbf{j} / m-\mathrm{CF}_{3} \mathrm{C}_{6} \mathrm{H}_{4}$ & $\mathrm{CN}$ & COOEt & 2 & $\mathrm{O}$ & $3 \mathbf{k}$ & 97 \\
\hline 12 & $\mathbf{1 k} / p-\mathrm{FC}_{6} \mathrm{H}_{4}$ & $\mathrm{CN}$ & COOEt & 2 & $\mathrm{O}$ & 31 & 92 \\
\hline 13 & 11 $/ m-\mathrm{FC}_{6} \mathrm{H}_{4}$ & $\mathrm{CN}$ & COOEt & 2 & $\mathrm{O}$ & $3 \mathrm{~m}$ & 93 \\
\hline 14 & $1 \mathrm{~m} / o-\mathrm{FC}_{6} \mathrm{H}_{4}$ & $\mathrm{CN}$ & COOEt & 2 & $\mathrm{O}$ & $3 n$ & 94 \\
\hline 15 & 1n $/ p-\mathrm{ClC}_{6} \mathrm{H}_{4}$ & $\mathrm{CN}$ & COOEt & 2 & $\mathrm{O}$ & 30 & 91 \\
\hline 16 & 1o $/ m-\mathrm{ClC}_{6} \mathrm{H}_{4}$ & $\mathrm{CN}$ & COOEt & 2 & $\mathrm{O}$ & $3 p$ & 94 \\
\hline 17 & $1 \mathbf{p} / p-\mathrm{BrC}_{6} \mathrm{H}_{4}$ & $\mathrm{CN}$ & COOEt & 2 & $\mathrm{O}$ & $3 q$ & 86 \\
\hline 18 & $1 q / \mathrm{C}_{6} \mathrm{H}_{5}$ & $\mathrm{CN}$ & COOEt & 2 & $\mathrm{O}$ & $3 \mathbf{r}$ & 98 \\
\hline 19 & 1r/ $/ p-\mathrm{MeC}_{6} \mathrm{H}_{4}$ & $\mathrm{CN}$ & COOEt & 2 & $\mathrm{O}$ & $3 s$ & 88 \\
\hline 20 & $\mathbf{1 s} / 3,4-\mathrm{Cl}_{2} \mathrm{C}_{6} \mathrm{H}_{3}$ & $\mathrm{CN}$ & COOEt & 2 & $\mathrm{O}$ & $3 t$ & 92 \\
\hline 21 & $\mathbf{1 t} / 2,4-\mathrm{Cl}_{2} \mathrm{C}_{6} \mathrm{H}_{3}$ & $\mathrm{CN}$ & COOEt & 2 & $\mathrm{O}$ & $3 \mathbf{u}$ & 93 \\
\hline 22 & $1 \mathbf{k} / p-\mathrm{FC}_{6} \mathrm{H}_{4}$ & $\mathrm{NO}_{2}$ & COOEt & 2 & $\mathrm{O}$ & $3 \mathbf{v}$ & 86 \\
\hline 23 & $\mathbf{1} \mathbf{u} / \mathrm{C}_{6} \mathrm{H}_{5}$ & $\mathrm{CN}$ & COOEt & 3 & $\mathrm{O}$ & $3 \mathbf{w}$ & 91 \\
\hline 24 & $\mathbf{1 v} / \mathrm{C}_{6} \mathrm{H}_{5}$ & $\mathrm{CN}$ & COOEt & 4 & $\mathrm{O}$ & $3 x$ & 88 \\
\hline 25 & $1 w / H$ & $\mathrm{CN}$ & COOEt & 4 & $\mathrm{O}$ & $3 y$ & 89 \\
\hline
\end{tabular}

${ }^{a}$ Reagents and conditions: $N, N^{\prime}$-disubstituted 1,1-ene diamines (DEDAMs) 1 (1.0 mmol), mercaptals $2(1.0 \mathrm{mmol}), \mathrm{Cs}_{2} \mathrm{CO}_{3}(2.0 \mathrm{mmol})$ and $\mathrm{CH}_{3} \mathrm{CN}(15.0 \mathrm{~mL}) .{ }^{b}$ Isolated yield based on DEDAMs 1 . 
$p$ - $\mathrm{BrC}_{6} \mathrm{H}_{4}$, alkyl, etc., were used as substrate and reacted with mercaptals 2a-2c. Ultimately, a series of pyridin-2-one derivatives 3a-3y were prepared by this method (Table 2, entries 1-25). The yields of the products reveal that the group of DEDAMs have a slight influence on the yields (Table 2, entries 1-10). DEDAMs 1 with electron-withdrawing groups $(\mathrm{F}, \mathrm{Cl})$ often can obtain higher yields than those with electron-donating group of DEDAMs (MeO, Me) (Table 2, entries 1-3 \& 7-9 vs. 5-6; 11-16 vs. 19). Longer chain DEDAMs $(n=2)$ produce the target compounds with higher yields (Table 2, 2 vs. 12; 3 vs. 15; 4-5 vs. 18-19) than those of the others. The longest chain DEDAMs ( $n=$ 3) gave the product with lowest yields compared with other DEDAMs ( $n=1$ or 2 ) (Table $2,4 \& 18$ vs. 24 ).

Surprisingly, we obtain excellent yield of the pyrimidin-4-one 4a when we use the $N$-monosubstituted 1,1-ene diamine (MEDAM) 1x as substrate in the reaction with ethyl 2-cyano-3,3bis(methylthio)-acrylate $\mathbf{2 a}$ under similar conditions as in Table 2 (Table 3, entries 1-6). To expand the scope and application of this method, $\mathrm{N}$-mono-substituted 1,1-ene diamines (MEDAMs) $(n=1,2)$ bearing the different aromatic groups, including $\mathrm{C}_{6} \mathrm{H}_{4}, p-\mathrm{MeC}_{6} \mathrm{H}_{4}$ and $p-\mathrm{FC}_{6} \mathrm{H}_{4}$, were also used as substrate and reacted with mercaptals $\mathbf{2 a} \& \mathbf{2 c}$. We obtained the pyrimidin-4-ones $\mathbf{4 a - 4 f}$ with excellent yields (92-98\%). These results demonstrate that MEDAMs are all good substrates for the regioselective reaction for the synthesis of pyrimidin-4-ones. The reactions only need take 4 hours in acetonitrile at refluxing and promoted by $\mathrm{Cs}_{2} \mathrm{CO}_{3}$.

All new compounds 3-4 were fully characterized by ${ }^{1} \mathrm{H}-\mathrm{NMR}$, ${ }^{13} \mathrm{C}-\mathrm{NMR}$ spectroscopy, high resolution mass spectroscopy and IR spectroscopy (see ESI $\dagger$ ). To further verify the structure of the pyridin-2-ones and pyrimidin-4-ones, the representative compound $3 \mathbf{f}$ \& $\mathbf{4 f}$ were verified by the X-ray crystallographic analysis (Fig. 2, CCDC 1549520 (ref. 44) and Fig. 3, CCDC 1553238 (ref. 45)†).

To illustrate the proposed putative mechanism for the regioselective synthesis of pyridin-2-ones 3 , the target

Table 3 Preparation of pyrimidin-4-ones $4 a-4 f^{a}$

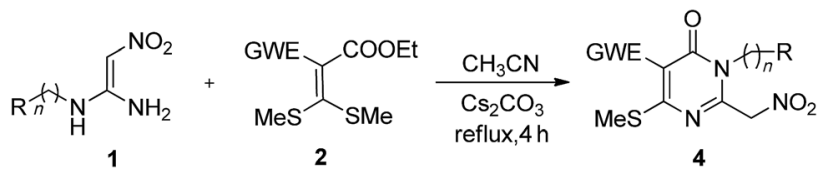

\begin{tabular}{llllll}
\hline Entry & $\mathbf{1} / \mathrm{R}$ & $\mathrm{EWG}$ & $n$ & Product & Yield $^{b}[\%]$ \\
\hline 1 & $\mathbf{1 x} / \mathrm{C}_{6} \mathrm{H}_{5}$ & $\mathrm{CN}$ & 1 & $\mathbf{4 a}$ & 93 \\
2 & $\mathbf{1} \mathbf{y} / p-\mathrm{MeC}_{6} \mathrm{H}_{4}$ & $\mathrm{CN}$ & 1 & $\mathbf{4 b}$ & 92 \\
3 & $\mathbf{1 z} / p-\mathrm{FC}_{6} \mathrm{H}_{4}$ & $\mathrm{CN}$ & 2 & $\mathbf{4 c}$ & 93 \\
4 & $\mathbf{1 a}^{\prime} / \mathrm{C}_{6} \mathrm{H}_{5}$ & $\mathrm{CN}$ & 2 & $\mathbf{4 d}$ & 96 \\
5 & $\mathbf{1 a}^{\prime} / \mathrm{C}_{6} \mathrm{H}_{5}$ & $\mathrm{NO}_{2}$ & 2 & $\mathbf{4 e}$ & 94 \\
6 & $\mathbf{1 b}^{\prime} / \mathrm{H}$ & $\mathrm{CN}$ & 4 & $\mathbf{4 f}$ & 98
\end{tabular}

${ }^{a}$ Reagents and conditions: $N$-monosubstituted 1,1-ene diamines (MEDAMs) 1 (1.0 mmol), mercaptals 2 (1.0 mmol), $\mathrm{Cs}_{2} \mathrm{CO}_{3}(2.0 \mathrm{mmol})$ and $\mathrm{CH}_{3} \mathrm{CN}(15.0 \mathrm{~mL}) .{ }^{b}$ Isolated yield MEDAMs 1 .

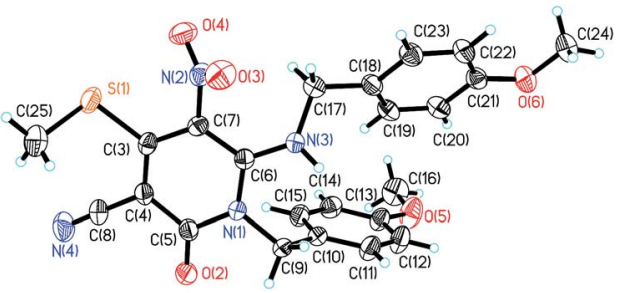

Fig. 2 X-ray crystal structures of $3 f$.

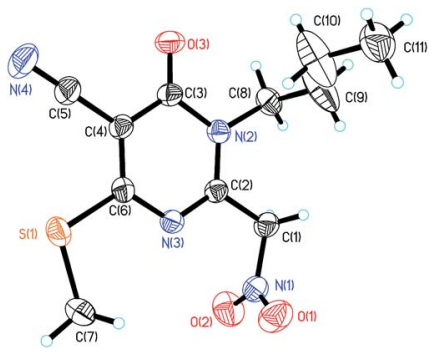

Fig. 3 X-ray crystal structures of $4 \mathrm{f}$.
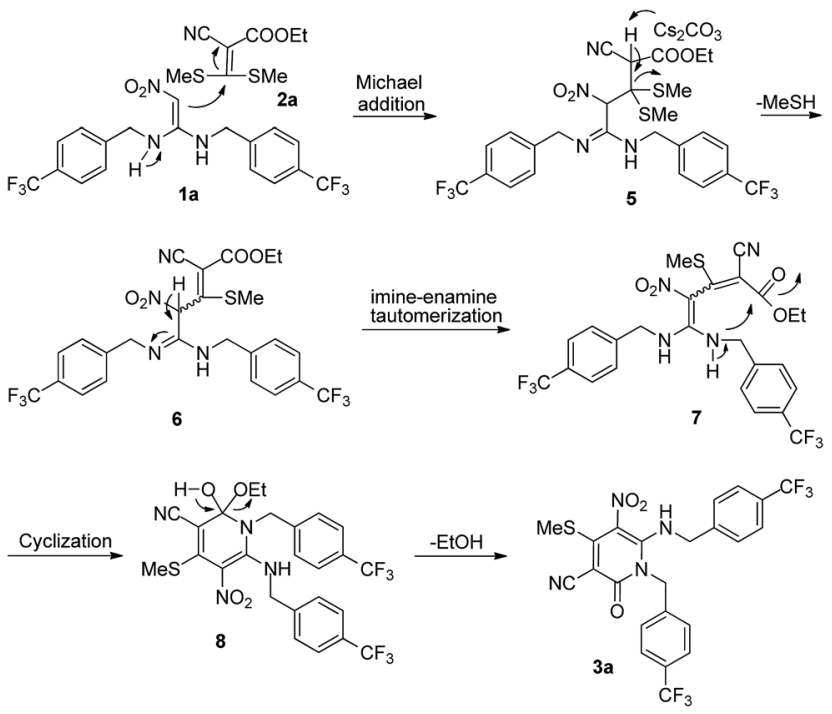

Scheme 1 Proposed mechanism for synthesis of compound 3a.

compounds 3a was used as the example (Scheme 1). First, the compound $\mathbf{1 a}$ is reacted with $\mathbf{2 a}$ via the Michael addition reaction to form the intermediate $\mathbf{5}$. Then, the intermediate $\mathbf{5}$ loses a molecule of $\mathrm{MeSH}$ in a reaction promoted by $\mathrm{Cs}_{2} \mathrm{CO}_{3}$, to produce the intermediate $\mathbf{6}$. Next, the intermediate 6 forms the compound 7 via imine-enamine tautomerization. After that, the compound 7 produces intermediate $8 \mathrm{via}$ an intramolecular cyclization reaction. Finally, the intermediate $\mathbf{8}$ loses one molecule of ethanol to form the target compound 3a.

The proposed putative mechanism for the synthesis of pyrimidin-4-ones $\mathbf{4}$ is shown in Scheme 2. First, compound 1 is 


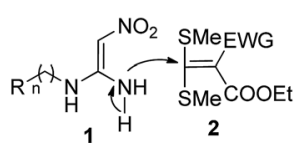<smiles>C[13CH3]</smiles>

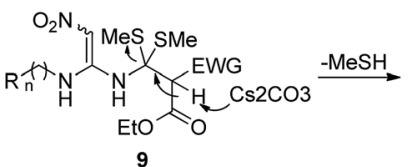

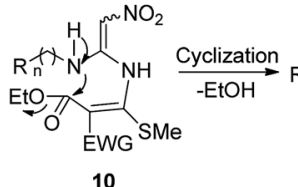<smiles>[R7]Cn1c(=O)c(C#N)c(OC)n(C=[N+]([O-])[O-])c1=O</smiles>

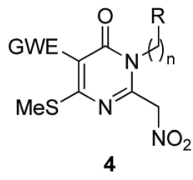

Scheme 2 Proposed mechanism for synthesis of compounds 4 .

reacted with 2 via the Michael addition reaction to produce the intermediate 9. Next, intermediate 9 loses one molecule of $\mathrm{MeSH}$ in a reaction promoted by the base $\mathrm{Cs}_{2} \mathrm{CO}_{3}$ and produces compound 10. Then, compound 10 forms compound 11 via intramolecular cyclization and loses one molecule of ethanol. Ultimately, compound $\mathbf{1 1}$ yields the products $\mathbf{4}$ via imineenamine tautomerization.

We selected the novel pyridin-2-ones 3 and pyrimidin-4-ones 4 to evaluate their in vitro anticancer activity against human cancer cells according to procedures described in the

Table 4 Cytotoxic activities of 3-4 in vitro ${ }^{a}\left(\mathrm{IC}_{50}, \mu \mathrm{mol} \mathrm{mL}^{-1}\right)^{b}$

\begin{tabular}{|c|c|c|c|c|c|}
\hline No. & Compound & SGC-7901 & Skov-3 & A549 & Hela \\
\hline 1 & $3 a$ & 11.13 & $>100$ & 62.56 & 29.08 \\
\hline 2 & $3 \mathbf{c}$ & 41.73 & 52.71 & 34.84 & 27.96 \\
\hline 3 & $3 d$ & 36.56 & $>100$ & 80.72 & 68.25 \\
\hline 4 & $3 e$ & 4.73 & 61.13 & 42.45 & 23.00 \\
\hline 5 & $3 f$ & 31.17 & 50.05 & 29.88 & $>100$ \\
\hline 6 & $3 g$ & 12.95 & $>100$ & $>100$ & 37.15 \\
\hline 7 & $3 h$ & 5.71 & $>100$ & 94.52 & $>40$ \\
\hline 8 & $3 \mathbf{i}$ & 15.85 & 28.95 & 22.83 & 58.90 \\
\hline 9 & $3 \mathbf{k}$ & 1.51 & 22.91 & 48.65 & 74.86 \\
\hline 10 & 31 & 9.81 & $>100$ & 47.74 & 15.45 \\
\hline 11 & $3 \mathrm{~m}$ & 2.26 & 12.38 & 4.15 & 12.30 \\
\hline 12 & $3 n$ & 4.89 & 21.06 & 5.58 & 15.94 \\
\hline 13 & 30 & 6.28 & 61.70 & 16.19 & 4.14 \\
\hline 14 & $3 p$ & $>100$ & 20.00 & 15.79 & 12.63 \\
\hline 15 & $3 q$ & 9.42 & 23.48 & 8.32 & 37.15 \\
\hline 16 & $3 \mathbf{r}$ & 6.79 & 12.28 & 4.22 & 3.26 \\
\hline 17 & $3 s$ & 3.02 & 28.95 & 25.69 & $>40$ \\
\hline 18 & $3 t$ & $>100$ & 6.98 & 3.00 & $96.14,14$ \\
\hline 19 & $3 \mathbf{u}$ & 2.55 & 21.94 & 8.07 & 23.00 \\
\hline 20 & $3 w$ & 23.65 & 17.95 & 25.57 & 23.00 \\
\hline 21 & $3 x$ & $>100$ & 23.64 & 13.12 & $>100$ \\
\hline 22 & $3 y$ & $>100$ & $>100$ & 27.18 & $>100$ \\
\hline 23 & $4 a$ & $>100$ & $>100$ & $>100$ & $>100$ \\
\hline 24 & $4 b$ & $>100$ & $>100$ & $>100$ & $>100$ \\
\hline 25 & $4 c$ & $>100$ & $>100$ & $>100$ & $>100$ \\
\hline 26 & $4 d$ & $>100$ & $>100$ & $>100$ & $>100$ \\
\hline 27 & $4 e$ & $>100$ & $>100$ & $>100$ & $>100$ \\
\hline 28 & 4f & $>100$ & $>100$ & $>100$ & $>100$ \\
\hline 29 & Cisplatin (DDP) & 11.00 & 12.78 & 15.32 & 9.94 \\
\hline
\end{tabular}

${ }^{a}$ Cytotoxicity as $\mathrm{IC}_{50}$ for each cell line, is the concentration of compound which reduced the optical density of treated cells by $50 \%$ with respect to untreated cells using the MTT assay. ${ }^{b}$ Data are represented as the mean values of three independent determinations. literature. ${ }^{46}$ The tumor cell line panel consisted of gastric cancer (SGC-7901), ovarian carcinoma (Skov-3), lung adenocarcinoma (A549), and Henrietta Lacks strain of cervical cancer (Hela). Cisplatin (DDP) was used as the reference drug. The results of the cytotoxicity data are summarized in Table $4\left(\mathrm{IC}_{50}\right.$ value, defined as the concentration corresponding to $50 \%$ growth inhibition). As shown in Table 4, some of the compounds exhibited excellent antitumor activity against the cancer cells. Actually, 3e, 3h, 3k-3o, 3q-3s and $\mathbf{3 u}$ are more active than cisplatin against SGC-7901 cells (Table 4, entries 4, 7, 9-13, 15-17 and 19). In particular, 3k is almost seven times more active against SGC-7901 cells than cisplatin (Table 4, entry 9). The data indicates that $N, N^{\prime}$-diphenethylethene-1,1-diamines $(n=2)$ are usually the most active against the SGC-7901 cells, the $N, N^{\prime}$-dibenzylethene-1,1-diamines $(n=1)$ are usually more active against SGC-7901 cells than $N, N^{\prime}$-bis(3-phenylpropyl) ethene-1,1-diamines $(n=3)$ (Table 4 , entries 1-8 vs. 9-19 vs. 20-22). Only three compounds $\mathbf{3 m}, \mathbf{3 r}$ and $3 \mathbf{t}$ are more active than cisplatin against Skov-3 cells (Table 4, entries 11, 16, 18). Seven compounds (3m, 3n, 3q, 3r 3t, 3u, and 3x) are more active than cisplatin against A549 cells (Table 4, entries 11, 12, 15, 16, 18, 19, 21). The results demonstrated that $N, N^{\prime}-$ diphenethylethene-1,1-diamines $(n=2)$ are usually the most active against the A549 cells, while the $N, N^{\prime}$-dibenzylethene-1,1diamines $(n=1)$ are usually less active against SGC-7901 cells than $N, N^{\prime}$-bis(3-phenylpropyl)ethene-1,1-diamines $(n=3)$ (Table 4, entries 9-19 vs. 20-22 vs. 1-8). Compound 3t is almost five times more active against A549 cells than cisplatin (Table 4, entry 18). Additionally, $3 \mathbf{s}$ and $\mathbf{3 r}$ are more potent against the tumor cell lines Hela (Table 4, entries 13 \& 16). Overall, $N, N^{\prime}-$ diphenethylethene-1,1-diamines $(n=2)$ usually are the most active compounds against the SGC-7901, Skov-3, A549 and Hela cells. Among them, compound $3 \mathbf{r}$ was more potent against the tumor cell lines SGC-7901, Skov-3, A549 and Hela than cisplatin (DDP) in all four cell lines (Table 4, entry 16). These results suggest that $N, N^{\prime}$-diphenethylethene-1,1-diamines $(n=2)$ play a key role in the modulation of the cytotoxic activities in these cancer cells (Scheme 3 \& Table 4). Additionally, the substituted group also has an influence on the cytotoxic activities. Generally, the contribution order of the groups of EDAMs to cytotoxic activities is $\mathrm{Ph}>p$ - $\mathrm{FPh}>m$ - $\mathrm{FPh}>p$-ClPh $>2,4-\mathrm{Cl}_{2} \mathrm{C}_{6} \mathrm{H}_{3} \approx 3,4-$ $\mathrm{Cl}_{2} \mathrm{C}_{6} \mathrm{H}_{3}>2,4-\mathrm{F}_{2} \mathrm{C}_{6} \mathrm{H}_{3} \approx 3,4-\mathrm{Cl}_{2} \mathrm{C}_{6} \mathrm{H}_{3}>p$-MePh $>p$-MeOPh.

However, pyrimidin-4-ones 4 does not have any antitumor activity. This finding clearly indicates that the two kinds of heterocycles have different antitumor activity.

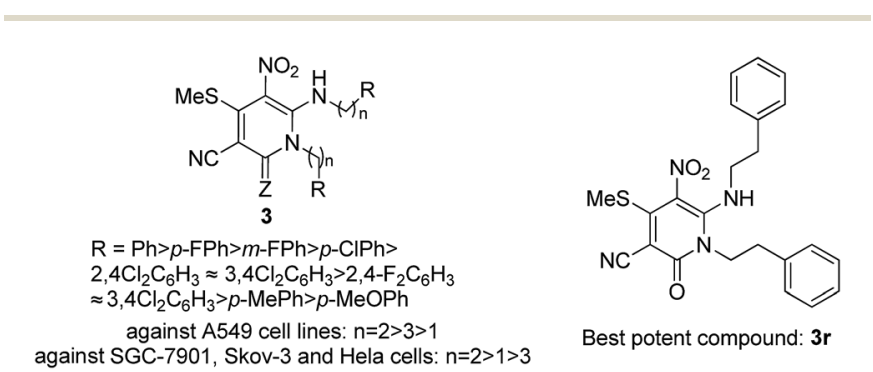

Scheme 3 Structure activity relationship of pyridin-2-ones 3. 


\section{Conclusions}

In conclusion, a concise and efficient method for the regioselective synthesis of two novel types of compounds including pyridin-2-ones 3 and pyrimidin-4-ones $\mathbf{4}$ had been developed. Pyridin-2-ones 3 was synthesised via the regioselective addition reaction of $N, N^{\prime}$-disubstituted 1,1-ene diamines $\mathbf{1 a}-\mathbf{1 w}$ with mercaptals 2a-2c in acetonitrile promoted by $\mathrm{Cs}_{2} \mathrm{CO}_{3}$ at refluxing. Remarkably, pyrimidin-4-ones 4 are obtained when $N$ monosubstituted 1,1-ene diamines $\mathbf{1} \mathbf{x}-\mathbf{1} \mathbf{b}^{\prime}$ are used as substrate in the reaction with mercaptals 2 under the same conditions. The reactions have some advantages, such as excellent yield, inexpensive raw materials and convenient final treatment. The screening of the antitumor bioactivity showed that some compounds exhibited potent antitumor activity. Especially, 3k which is almost seven times more active against SGC-7901 cells than cisplatin. Compound $\mathbf{3 t}$ is almost five times more active against A549 cells than cisplatin. On the whole, compounds 3r proved to be the most potent derivative with $\mathrm{IC}_{50}$ values lower than $12.3 \mu \mathrm{mol} \mathrm{L}{ }^{-1}$ of against all four human tumor cell lines, which makes it more active than cisplatin (DDP).

\section{Experimental section}

All compounds were fully characterized by spectroscopic data. The NMR spectra were recorded on a Bruker DRX500 $\left({ }^{1} \mathrm{H}: 500\right.$ $\left.\mathrm{MHz},{ }^{13} \mathrm{C}: 125 \mathrm{MHz}\right)$ or DRX600 $\left({ }^{1} \mathrm{H}: 600 \mathrm{MHz},{ }^{13} \mathrm{C}: 150 \mathrm{MHz}\right)$, chemical shifts $(\delta)$ are expressed in ppm, and $J$ values are given in $\mathrm{Hz}$, deuterated DMSO- $d_{6}$ or $\mathrm{CDCl}_{3}$ was used as solvent. IR spectra were recorded on a FT-IR Thermo Nicolet Avatar 360 using $\mathrm{KBr}$ pellet. The reactions were monitored by thin layer chromatography (TLC) using silica gel $\mathrm{GF}_{254}$. The melting points were determined on XT-4A melting point apparatus and are uncorrected. HRMs were performed on an Agilent LC/Msd TOF instrument. All chemicals and solvents were used as received without further purification unless otherwise stated. Compounds 1 were obtained according to the literature. ${ }^{47}$ The synthetic method of compound 2 according the literature. ${ }^{48}$ Fetal bovine serum (FBS) was purchased from Hyclone Laboratories (Logan, UT, USA). The tumor cell line panel consisted of gastric cancer (SGC-7901), ovarian carcinoma (Skov-3), lung adenocarcinoma (A549), and Henrietta Lacks strain of cervical cancer (Hela) were obtained from American Type Culture Collection.

\section{General procedure to prepare pyridin-2-ones 3}

$N, N^{\prime}$-Disubstituted 1,1-ene diamines (DEDAMs) 1 (1.0 $\left.\mathrm{mmol}\right)$, mercaptals $2(1.0 \mathrm{mmol}), \mathrm{Cs}_{2} \mathrm{CO}_{3}(2.0 \mathrm{mmol})$, acetonitrile $(15.0 \mathrm{~mL})$ were added into a $25 \mathrm{~mL}$ round-bottom flask, the mixture at reflux for about $8 \mathrm{~h}$ and monitored by thin layer chromatography (TLC) until the DEDAMs 1 substrate was completely consumed. After the completion of the reaction, the reaction system was cooled to room temperature. The reaction mixture was poured into $25 \mathrm{~mL}$ of water and ethyl acetate for extraction and separation. Then the crude product was collected by filtering and enrichment, which was purified by column chromatography (petroleum ether/EtOAc $=10: 1$ ) or recrystallization and obtained a series of pyridin-2-one compounds 3 with $83-98 \%$ yield.

4-(Methylthio)-5-nitro-2-oxo-1-(4-(trifluoromethyl)benzyl)-6((4-(trifluoromethyl)-benzyl)amino)-1,2-dihydropyridine-3carb-onitrile (3a)

Yellow solid, mp 159.1-160.2 ${ }^{\circ} \mathrm{C}$; IR (KBr): 3413, 2316, 1638, 1618, 1328, 1165, 1124, $1069 \mathrm{~cm}^{-1}$; ${ }^{1} \mathrm{H}$ NMR (600 MHz, DMSO$\left.d_{6}\right): \delta=2.74\left(\mathrm{~s}, 3 \mathrm{H}, \mathrm{CH}_{3}\right), 4.17\left(\mathrm{~m}, 2 \mathrm{H}, \mathrm{CH}_{2}\right), 5.47\left(\mathrm{~m}, 2 \mathrm{H}, \mathrm{CH}_{2}\right)$, 7.14-7.16 (m, 2H, ArH), 7.35-7.37 (m, 2H, ArH), 7.44-7.45 (m, 2H, ArH), 7.66-7.68 (m, 2H, ArH), 8.37 (br, $1 \mathrm{H}, \mathrm{NH}) ;{ }^{13} \mathrm{C} \mathrm{NMR}$ (150 MHz, DMSO- $\left.d_{6}\right): \delta=19.4,45.3,49.2,89.2,116.8,122.0$, $122.7,123.6,123.8,125.2$, 125.3, 125.7, 125.9, 127.2, 127.4, 128.7, 128.7, 129.2, 139.5, 140.9, 149.9, 156.2, 159.2; HRMS (ESITOF): $m / z$ calcd for $\mathrm{C}_{23} \mathrm{H}_{15} \mathrm{~F}_{6} \mathrm{~N}_{4} \mathrm{O}_{3} \mathrm{~S}[\mathrm{M}-\mathrm{H}]^{-}, 541.0775$; found, 541.0773 .

1-(4-Fluorobenzyl)-6-((4-fluorobenzyl)amino)-4-(methylthio)-5nitro-2-oxo-1,2-dihydropyridine-3-carbonitrile (3b)

Yellow solid, mp 177.8-178.0 ${ }^{\circ} \mathrm{C}$; IR (KBr): 3334, 1639, 1554, 1512, 1494, 1466, 1328, $1235 \mathrm{~cm}^{-1}$; ${ }^{1} \mathrm{H}$ NMR (600 MHz, DMSO$\left.d_{6}\right): \delta=2.72\left(\mathrm{~s}, 3 \mathrm{H}, \mathrm{CH}_{3}\right), 4.10\left(\mathrm{~m}, 2 \mathrm{H}, \mathrm{CH}_{2}\right), 5.36\left(\mathrm{~m}, 2 \mathrm{H}, \mathrm{CH}_{2}\right)$, 6.97-7.02 (m, 4H, ArH), 7.14-7.21 (m, 4H, ArH), 8.31 (br, 1H, $\mathrm{NH}) ;{ }^{13} \mathrm{C}$ NMR $\left(150 \mathrm{MHz}, \mathrm{DMSO}-d_{6}\right): \delta=19.4,44.9,49.0,89.0$, $115.3,115.5,115.8,115.9,116.9,122.6,128.9,129.0,130.6$, 130.7, 132.3 132.3, 149.8, 156.0, 159.2 , 162.1, 162.1; HRMS (ESITOF): $m / z$ calcd for $\mathrm{C}_{21} \mathrm{H}_{15} \mathrm{~F}_{2} \mathrm{~N}_{4} \mathrm{O}_{3} \mathrm{~S}[\mathrm{M}-\mathrm{H}]^{-}, 441.0838$; found, 441.0836 .

\section{General procedure for prepared pyrimidin-4-ones 4}

$\mathrm{N}$-Monosubstituted 1,1-ene diamines (MEDAMs) 1 (1.0 mmol), mercaptals $2(1.0 \mathrm{mmol}), \mathrm{Cs}_{2} \mathrm{CO}_{3}(2.0 \mathrm{mmol})$ and acetonitrile $(15.0 \mathrm{~mL})$ were added into a $25 \mathrm{~mL}$ round-bottom flask, the mixture at reflux for about $4 \mathrm{~h}$ and monitored by TLC until the MEDAMs 1 substrate was completely consumed. After the completion of the reaction, the reaction system was cooled to room temperature. The reaction mixture was poured into $25 \mathrm{~mL}$ of water and $25 \mathrm{~mL}$ ethyl acetate for extraction and separation. Then the crude product was collected by filtering and enrichment, which was purified by column chromatography (petroleum ether/EtOAc $=3: 1$ ) and obtained a series of pyrimidin-4ones 4 with $92-98 \%$ yield.

\section{1-Benzyl-4-(methylthio)-2-(nitromethyl)-6-oxo-1,6-dihydropy-} rimidine-5-carbonitrile (4a)

Orange solid, mp 115.0-116.2 ${ }^{\circ} \mathrm{C}$; IR (KBr): 3291, 2926, 2206, 1506, 1439, 1291, 1215, $832 \mathrm{~cm}^{-1}$; ${ }^{1} \mathrm{H}$ NMR (500 MHz, DMSO$\left.d_{6}\right): \delta=2.54\left(\mathrm{~s}, 3 \mathrm{H}, \mathrm{CH}_{3}\right), 5.25\left(\mathrm{~m}, 2 \mathrm{H}, \mathrm{CH}_{2}\right), 6.11\left(\mathrm{~s}, 2 \mathrm{H}, \mathrm{CH}_{2}\right)$, 7.27-7.32 (m, 2H, ArH), 7.32-7.39 (m, 3H, ArH); ${ }^{13} \mathrm{C}$ NMR (125 MHz, DMSO- $\left.d_{6}\right): \delta=13.4,47.2,78.1,94.1,114.1,127.3,127.3$, 128.4, 129.3, 129.3, 134.4, 154.8, 158.2, 174.3; HRMS (ESI-TOF): $m / z$ calcd for $\mathrm{C}_{14} \mathrm{H}_{11} \mathrm{~N}_{4} \mathrm{O}_{3} \mathrm{~S}[\mathrm{M}-\mathrm{H}]^{-}, 315.0557$; found, 315.0546 . 
1-(4-Methylbenzyl)-4-(methylthio)-2-(nitromethyl)-6-oxo-1,6dihydropyrimidine-5-carbonitrile $(4 \mathrm{~b})$

White solid, mp 158.0-158.5 ${ }^{\circ} \mathrm{C}$; IR (KBr): 3441, 2930, 2222, 1684, 1572, 1506, 1379, $974 \mathrm{~cm}^{-1} ;{ }^{1} \mathrm{H}$ NMR (500 MHz, DMSO$\left.d_{6}\right): \delta=2.29\left(\mathrm{~s}, 3 \mathrm{H}, \mathrm{CH}_{3}\right), 2.53\left(\mathrm{~s}, 3 \mathrm{H}, \mathrm{CH}_{3}\right), 5.21\left(\mathrm{~m}, 2 \mathrm{H}, \mathrm{CH}_{2}\right)$, $6.10\left(\mathrm{~s}, 2 \mathrm{H}, \mathrm{CH}_{2}\right), 7.18$ (m, 4H, ArH); ${ }^{13} \mathrm{C}$ NMR (125 MHz, DMSO$\left.d_{6}\right): \delta=13.4,21.1,46.9,78.1,94.0,114.1,126.9,127.1,129.9$, 129.9, 131.4, 137.8, 154.8, 158.2, 174.2; HRMS (ESI-TOF): $\mathrm{m} / \mathrm{z}$ calcd for $\mathrm{C}_{15} \mathrm{H}_{13} \mathrm{~N}_{4} \mathrm{O}_{3} \mathrm{~S}[\mathrm{M}-\mathrm{H}]^{-}, 329.0714$; found 329.0703 .

\section{Conflicts of interest}

There are no conflicts to declare.

\section{Acknowledgements}

This work was supported by the National Natural Science Foundation of China (No. 21362042, 21662042, U1202221, 21262042), the Natural Science Foundation of Yunnan Province (No. 2017FA003), the Reserve Talent Foundation of Yunnan Province for Middle-aged and Young Academic and Technical Leaders (No. 2012HB001), Donglu Schloars of Yunnan University, Excellent Young Talents, Yunnan University, and HighLevel Talents Introduction Plan of Yunnan Province.

\section{Notes and references}

1 (a) L. Ren, J. Grina, D. Moreno, J. F. Blake, J. J. Gaudino, R. Garrey, A. T. Metcalf, M. Burkard, M. Martinson, K. Rasor, H. Chen, B. Dean, S. E. Gould, P. Pacheco, S. Shahidi-Latham, J. Yin, K. West, W. Wang, J. G. Mo and J. B. Schwarz, J. Med. Chem., 2015, 58, 1976; (b) L. Wang, J. K. Pratt, T. Soltwedel, G. S. Sheppard, S. D. Fidanze, D. Liu, L. A. Hasvold, R. A. Mantei, J. H. Holms, W. J. McClellan, M. D. Wendt, C. Wada, R. Frey, T. M. Hansen, R. Hubbard, C. H. Park, L. Li, T. J. Magoc, D. H. Albert, X. Lin, S. E. Warder, P. Kovar, X. Huang, D. Wilcox, R. Wang, G. Rajaraman, A. M. Petros, C. W. Hutchins, S. C. Panchal, C. Sun, S. W. Elmore, Y. Shen, W. M. Kati and K. F. McDaniel, J. Med. Chem., 2017, 60, 3828.

2 J. A. D. Good, J. Silver, C. Núñez-Otero, W. Bahnan, K. S. Krishnan, O. Salin, P. Engström, R. Svensson, P. Artursson, A. Gylfe, S. Bergström and F. Almqvist, $J$. Med. Chem., 2016, 59, 2094.

3 J. M. Cid, G. Tresadern, G. Duvey, R. Lütjens, T. Finn, J.-P. Rocher, S. Poli, J. A. Vega, A. de Lucas, E. Matesanz, M. L. Linares, J. I. Andrés, J. Alcazar, J. M. Alonso, G. J. Macdonald, D. Oehlrich, H. Lavre, A. Ahnaous, W. Drinkenburg, C. Mackie, S. Pype, D. Gallacher and A. A. Trabanco, J. Med. Chem., 2014, 57, 6495.

4 K. L. Van, C. Cauvin, S. de Walque, B. Georges, S. Boland, V. Martinelli, D. Demonte, F. Durant, L. Hevesi and C. V. Lint, J. Med. Chem., 2009, 52, 3636.
5 J. M. Hoffman, J. S. Wai, C. M. Thomas, R. B. Levin, J. A. O'Brien and M. E. Goldman, J. Med. Chem., 1992, 35, 3784.

6 J. M. Hoffman, A. M. Smith, C. S. Rooney, T. E. Fisher, J. S. Wai, C. M. Thomas, D. L. Bamberger, J. L. Barnes and T. M. Williams, J. Med. Chem., 1993, 36, 953.

7 W. S. Saari, J. S. Wai, T. E. Fisher, C. M. Thomas, J. M. Hoffman, C. S. Rooney, A. M. Smith, J. H. Jones and D. L. Bamberger, J. Med. Chem., 1992, 35, 3792.

8 J. S. Wai, T. M. Williams, D. L. Bamberger, T. E. Fisher, J. M. Hoffman, R. J. Hudcosky, S. C. MacTough, C. S. Rooney and W. S. Saari, J. Med. Chem., 1993, 36, 249.

9 W. S. Saari, J. M. Hoffman, J. S. Wai, T. E. Fisher, C. S. Rooney, A. M. Smith, C. M. Thomas, M. E. Goldman and J. A. O'Brien, J. Med. Chem., 1991, 34, 2922.

10 N. A. Hamdy and A. M. Gamal-Eldeen, Eur. J. Med. Chem., 2009, 44, 4547.

11 Z. Lv, C. Q. Sheng, T. T. Wang, Y. K. Zhang, J. Liu, J. L. Feng, H. L. Sun, H. Y. Zhong, C. J. Niu and K. Li, J. Med. Chem., 2010, 53, 660 .

12 G. C. Moraski, L. D. Markley, P. A. Hipskind, H. Boshoff, S. Cho, S. G. Franzblau and M. J. Miller, ACS Med. Chem. Lett., 2011, 2, 466.

13 J. J. Parlow, R. G. Kurumbail, R. A. Stegeman, A. M. Stevens, W. C. Stallings and M. S. South, J. Med. Chem., 2003, 46, 4696.

14 R. W. Hartmann and M. Reichert, Arch. Pharm., 2000, 333, 145.

15 V. S. Prasadarao Lingam, D. H. Dahale, V. E. Rathi, Y. B. Shingote, R. R. Thakur, A. S. Mindhe, S. Kummari, N. Khairatkar-Joshi, M. Bajpai, D. M. Shah, R. S. Sapalya, S. Gullapalli, P. K. Gupta, G. S. Gudi, S. B. Jadhav, R. Pattem and A. Thomas, J. Med. Chem., 2015, 58, 8292.

16 H. J. Jessen and K. Gademann, Nat. Prod. Rep., 2010, 27, 1168.

17 M. Ando, T. Wada and N. Sato, Org. Lett., 2006, 8, 3805.

18 H. Schirok, C. Alonso-Alija, J. Benet-Buchholz, A. H. Göller, R. Grosser, M. Michels and H. Paulsen, J. Org. Chem., 2005, 70, 9463.

19 M. P. Balu, G. Singh, H. lla and H. Junjappa, Tetrahedron Lett., 1986, 27, 117.

20 J. Marinello, C. Marchand, B. T. Mott, A. Bain, C. J. Thomas and Y. Pommier, Biochemistry, 2008, 47, 9345.

21 F. Manetti, J. A. Esté, I. Clotet-Codina, M. Armand-Ugón, G. Maga, E. Crespan, R. Cancio, C. Mugnaini, C. Bernardini, A. Togninelli, C. Carmi, M. Alongi, E. Petricci, S. Massa, F. Corelli and M. Botta, J. Med. Chem., 2005, 48, 8000.

22 D. Rotili, D. Tarantino, M. B. Nawrozkij, A. S. Babushkin, G. Botta, B. Marrocco, R. Cirilli, S. Menta, R. Badia, E. Crespan, F. Ballante, R. Ragno, J. A. Esté, G. Maga and A. Mai, J. Med. Chem., 2014, 57, 5212.

23 K. K. Ariën, M. V. Johan Michiels, J. Joosens, K. Vereecken, P. V. D. Veken, S. Abdellati, V. Cuylaerts, T. Crucitti, L. Heyndrickx, J. Heeres, K. Augustyns, P. J. Lewi and G. Vanham, J. Antimicrob. Chemother., 2013, 68, 2038. 24 M. M. Hossain and M. A. Parniak, J. Virol., 2006, 80, 4440. 
25 O. J. D'Cruz and F. M. Uckun, J. Antimicrob. Chemother., 2006, 57, 411.

26 Q. Abdool Karim, S. S. Abdool Karim, J. A. Frohlich, A. C. Grobler, C. Baxter, L. E. Mansoor, A. B. M. Kharsany, S. Sibeko, K. P. Mlisana, Z. Omar, T. N. Gengiah, S. Maarschalk, N. Arulappan, M. Mlotshwa, L. Morris and D. Taylor, Science, 2010, 329, 1168.

27 J. Younkin, S. A. Gaitonde, A. Ellaithy, R. Vekariya, L. Baki, J. L. Moreno, S. Shah, P. Drossopoulos, K. S. Hideshima, J. M. Eltit, J. González-Maeso, D. E. Logothetis, M. Dukat and R. Glennon, ACS Chem. Neurosci., 2016, 7, 1292.

28 S. D. Turco, S. Sartini, C. Sentieri, C. Saponaro, T. Navarra, B. Dario, F. D. Settimo, C. L. Motta and G. Basta, Eur. J. Med. Chem., 2014, 72, 102.

29 Y.-L. Li, B. W. Metcalf and A. P. Combs, EP2448938, 2015. 30 R. A. Nugent and S. T. Schlachter, WO9511235A1, 1995.

31 J. Bagli, T. Bogri, B. Palameta, S. Rakhit, S. Peseckis, J. McQuillan and D. K. H. Lee, J. Med. Chem., 1988, 31, 814.

32 K. M. Belyk, H. G. Morrison, P. Jones and V. Summa, WO2006060712A2, 2006.

33 C. Hoornaert, and A. Wick, EP607077A1, 1994.

34 Y. S. Chun, J. H. Kim, S. Y. Choi, Y. O. Ko and S. Lee, Org. Lett., 2012, 14, 6358.

35 (a) B. Zhou, Z.-C. Liu, W.-W. Qu, R. Yang, X.-R. Lin, S.-J. Yan and J. Lin, Green Chem., 2014, 16, 4359; (b) F.-C. Yu, Z.-Q. Chen, X.-P. Hao, S.-J. Yan, R. Huang and J. Lin, RSC Adv., 2014, 4, 6110; (c) L. Chen, R. Huang, X.-X. Du, S.-J. Yan and J. Lin, ACS Sustainable Chem. Eng., 2017, 5, 1899.

36 (a) X. B. Chen, Z.-C. Liu, L.-F. Yang, S.-J. Yan and J. Lin, ACS Sustainable Chem. Eng., 2014, 2, 1155; (b) X.-B. Chen, Z.-C. Liu, X.-R. Lin, R. Huang, S.-J. Yan and J. Lin, ACS Sustainable Chem. Eng., 2014, 2, 2391.

37 (a) F.-C. Yu, X.-R. Lin, Z.-C. Liu, J.-H. Zhang, F.-F. Liu, W. Wu, Y.-L. Ma, W.-W. Qu, S.-J. Yan and J. Lin, ACS Omega, 2017, 2, 873; (b) K.-M. Wang, Y.-L. Ma, X.-R. Lin, S.-J. Yan and J. Lin, RSC Adv., 2015, 5, 36472.
38 (a) M. Papmeyer, C. A. Vuilleumier, G. M. Pavan, K. O. Zhurov and K. Severin, Angew. Chem., Int. Ed., 2016, 55, 1685; (b) N. Poomathi, P. T. Peumal and S. Ramakrishna, Green Chem., 2017, 19, 2524.

39 Sunesis pharmaceuticals, INC. WO2006/65703 A1, 2006.

40 H. Schirok, C. Alonso-Alija, J. Benet-Buchholz, A. H. Goeller, R. Grosser, M. Michels and H. Paulsen, J. Org. Chem., 2005, 70, 9463.

41 (a) A. M. Kelly-Rowley, V. M. Lynch and E. V. Anslyn, J. Am. Chem. Soc., 1995, 117, 3438; (b) A. M. Kelly-Rowley, L. A. Cabell and E. V. Anslyn, J. Am. Chem. Soc., 1991, 113, 9687; (c) A. Alizadeh, A. Zarei and A. Rezvanian, Synthesis, 2011, 3, 497.

42 (a) S. Lu, X. Shao, Z. Li, Z. Xu, S. Zhao, Y. Wu and X. Xu, J. Agric. Food Chem., 2012, 60, 322; (b) N. Chen, X. Meng, F. Zhu, J. Cheng, X. Shao and Z. Li, J. Agric. Food Chem., 2015, 63, 1360; (c) H. Bao, X. Shao, Y. Zhang, Y. Deng, X. Xu, Z. Liu and Z. Li, J. Agric. Food Chem., 2016, 64, 5148; (d) L.-R. Wen, Z.-R. Li, M. Li and H. Cao, Green Chem., 2012, 14, 707.

43 (a) A. Maryamabadi, A. Hasaninejad, N. Nowrouzi, G. Mohbbi and B. Asghari, Bioorg. Med. Chem., 2016, 24, 1408; (b) A. Maryamabadi, A. Hasaninejad, N. Nowrouzi and G. Mohebbi, Bioorg. Med. Chem., 2017, 25, 2507.

44 CCDC 1549520 contain the supplementary crystallographic data for compound $3 \mathrm{f} . \dagger$

45 CCDC 1553238 contain the supplementary crystallographic data for compound $\mathbf{4 f} . \dagger$

46 S.-J. Yan, C. Huang, X.-H. Zeng, R. Huang and J. Lin, Bioorg. Med. Chem. Lett., 2010, 20, 48.

47 R. C. da Silva, G. P. da Silva, D. P. Sangi, J. G. de M. Pontes, A. G. Ferreira, A. G. Corrêa and M. W. Paixão, Tetrahedron, 2013, 69, 9007.

48 (a) W. M. Al-Adiwish, M. I. M. Tahir and W. A. Yaacob, Synth. Commun., 2013, 43, 3203; (b) Y.-C. Wu, H.-J. Li and H.-Z. Yang, Org. Biomol. Chem., 2010, 8, 3394. 